\title{
Introduction: Aid-effectiveness, Prisoners' Dilemmas, and Country Allocations
}

\author{
Michael Lipton
}

I

Despite their diverse origins ${ }^{1}$ - and despite the deliberate inclusion of one outspokenly sceptical view of aid - these eleven papers imply clear conclusions about aid-effectiveness. 1. Most aid raises growth and/or reduces poverty (Section II). 2. A disturbingly large, possibly rising, proportion does neither. 3. Partly, this is because much aid serves mostly donor interests. 4. Partly, it is because of inappropriate recipient policies (Section III). 5. Donors' interests impede their, and recipients', efforts to improve recipients' policies. 6. Each donor to, and each ministry in, a recipient country is imprisoned in a dilemma. By pursuing self-interested policies, it often harms aid-effectiveness in that country (for all donors and ministries). By avoiding them, it may lose out to less scrupulous donors and ministries. 'Coordination' is not a magic solution (Section IV). 7. Macroeconomic conditions - unlike sect or dialogues - seldom work, but may be implicit in a shift from project to programme aid. 8. That shift, and the associated aid shift to Africa, require better institutional and manpower aid, to maintain adequate effectiveness of other aid (Section V). 9. Many factors - the limitations of conditionality; the record of antipoverty aid; the record of inefficiency, inequality, and arguably near-scandal, in aid allocation among recipients - suggest that major country reallocations are the key to increased aid-effectiveness (Section VI).

\footnotetext{
Two papers in this Bulletin (plus some of this Introduction) derive from lectures to a series, on 'Financial Flows to Developing Countries', which I directed at All Souls College, Oxford, in 1984. Eight papers derive from work for the study of aid-effectiveness, commissioned by the Task Force on Concessional Flows (representatives of 18 governments, chosen by the Finance Ministers of all Bank-Fund member countries), and directed by Robert Cassen. His summary paper [Cassen 1986, 1986a; see also Burki and Ayres 1986], and another outstanding review too recent for discussion here, [Krueger 1986] should be read in conjunction with this Bulletin. However, my Introduction in no way summarises Cassen's work, and in some ways differs from it, so that I am more than usually grateful for his helpful comments.
}

II

There are massive data problems in establishing whether, where, or when aid raises growth or reduces poverty. The official definition of 'aid' includes some flows that are disguised military support ('officially' not supposed to be aid), and some flows to quite rich countries - but excludes many 'official' flows at below-market rates that are only partly concessional. In assessing effectiveness it is not clear whether gross, net, or grant-equivalent 'aid' should be measured. GNP growth and (especially) poverty data are notoriously weak, especially in the (apparently) poorest or slowest-growing countries. A large crosscountry sample [Mosley 1986] thus risks major biases in assessing aid-effectiveness; but a small sample, eg of 'high aid receivers' [Griffin ${ }^{2}$ ] risks different biases, of selectivity. Even the scale of aid depends on the measure: small and falling, compared to donor GNP and recipient population [Griffin] and to the requirements of poverty reduction [Chaudhuri]; large and rising, compared to investment or imports or public expenditure, in African low-income countries, and in Bangladesh [Hewitt and Kydd, Duncan, Van Arkadie].

There are familiar traps. Except in the very long run, the ratio of aid to GNP - or to growth - is 'automatically' boosted by a big aid rise, or by a period of sluggish or negative GNP growth; that makes countries with more aid look like slow growers, and makes slow growers look heavily aided [Griffin]. Or aid may deliberately be allocated to slow growers [Mosley], taking time to perk them up, if it does. Both factors can misleadingly suggest perverse aid-growth relationships.

Nevertheless - while the once convincing nationallevel evidence linking aid to growth [Papenek 1972] now looks dubious [Mosley 1986] - there is strong evidence from project evaluations that most aid [World Bank 1985] and most technical cooperation [Muscat] is successful and high-yielding, and theory gives some

2 Undated references are to papers in this Bulletin.

IDS Bulletin. 1986, vol 17 no 2. Institute of Development Studies. Sussex 
support to this. Project evaluations for several agencies are critical, frank, and genuinely independent - though unfortunately seldom published, and, except for the Bank, omitting many projects and little used for feedback [Muscat]. While usually favourable on rates of return in major sectors and regions [Mosley], such evaluations cast doubt on the capacity of aid to reach the very poorest, and the limitations of 'integrated rural development' are redirecting donor attention towards public works and even food subsidy [Chaudhuri]. Perhaps it is not sensible to expect aid to alleviate poverty if governments are reluctant, but it is even less sensible to expect aid withdrawal to remove the reluctance [Van Arkadie].

As for theory, the much-maligned 'Harrod-Domar' approach can help us to analyse what aid does. The approach, really a tautology, asserts that a country's growth-rate is the product of (a) the proportion of its GNP that it can use for purposes other than consumption and defence, i.e. for 'savings' in the broadest sense, including education, health, etc., and (b) the efficiency of such 'savings' in causing growth. The proportion (a) comprises domestic and foreign 'savings'. More aid is one way to raise foreign 'savings' - for a very poor country, attracting little cash from foreign banks or businesses, almost the only way. Such aid must increase growth, unless it crowds out substantial amounts of the other part of (a) domestic 'saving' - and/or greatly reduces (b), the efficiency with which total 'saving' is turned into extra output.

On (a), Kenya experienced some 'crowding out' of private savings-and-investment by aid - and probably some switching, as aid-backed investments made the government sector feel freer to consume instead [Mosley]. Malawi probably suffered none of the latter effect, due to its 'fiscal conservatism' [Hewitt and Kydd]. One estimate is that one dollar more aid to a typical poor country 'crowds out' 48 cents of domestic saving [Griffin] — though most other estimates are lower [Weisskopf 1972; Mosley 1980], and recent work [Lavy 1985] shows that only consumption-specific aid (eg food aid), not investment aid, adds significantly less than its own value to the recipient country's investment. As for (b), the partly non-developmental motives of the US Economic Support Fund [Griffin], the UK Aid and Trade Provision, and mixed credits generally [Ryrie] inevitably cut the returns to some aid, and hence the efficiency with which total 'savings' produce output; conversely much aid - strikingly that to India's agricultural research and development [Toye] and to primary health care - raises such efficiency, by piloting successful investments and institutions.

Suppose aid comprises one quarter of a country's total 'savings' of $\$ 500 \mathrm{mn}$ (20 per cent of GNP), and implausibly - that each extra aid dollar cuts domestic savings by as much as 48 cents. Aid then doubles; could this fail to raise the growth rate? The extra $\$ 125 \mathrm{mn}$ of aid crowds out $\$ 60 \mathrm{mn}$ of domestic 'saving', so total 'saving' rises from 20 per cent to 22.6 per cent of GNP. Typically, four units of 'saving' produce about one unit of 'growth'. For the extra aid to generate no, or negative, extra growth, this efficiency ratio would have to deteriorate from 4 to 4.525 or worse. There is no evidence that aid has so large (or any) negative net effect on total capital efficiency; yet if, as most of the evidence suggests, aid 'crowds out' much less than 48 per cent of its value in domestic savings, the net efficiency damage has to be even worse, if it is to prevent aid from accelerating growth.

\section{III}

Nevertheless, the trend of rates of return on aid projects, as estimated at project completion in each of the World Bank's last four Annual Reviews of Project Performance Audits, is deteriorating. This is echoed in the trend of Kenyan evaluations at project completion, despite the shortage of 'impact studies' to follow up returns a few years afterwards [Duncan]. In Bangladesh, projects satisfactory on completion often proved non-sustainable, requiring costly 'rehabilitation' afterwards [Van Arkadie]. A World Bank 'sustainability study' in 1985 (project details are confidential) reported that - of a small non-random selection (27) of their many agricultural projects that had yielded satisfactory returns at post-completion audits during 1975-81 - only nine were performing adequately when revisited for 'impact studies', typically three to five years later. In sub-Saharan Africa, it was only one out of 13 projects!

There are three types of reason for this. First, sheer $b a d$ luck should not be underestimated. In the 1980s (when most 'impact studies' were done), drought, debt or commodity slump have wrought havoc, not just with African aid, but among most Third World investments, private (eg in Brazil) and public, foreign- and domestic-financed alike. In Africa especially, recession savagely reduced the capacity of governments to provide current cash to meet their obligations in support of aid projects - and this reduced the projects' return. Second, recipient policy error is the usual focus of concern; in particular, farmers' prices (and the domestic value of their foreign sales) can be depressed by policy, thus reducing their incentives to raise output by working with aid-financed projects [Hewitt and Kydd, Duncan, Ryrie]. Probably a much more serious 'incentive reducer' has been publicsector neglect of farm investment, delivery and research. Third, donor policy error, too, can reduce 
returns to aid. Political and commercial interests in aid, if overt, are perfectly legitimate, and tied aid thanks to a commercial lobby, is normally better than no aid [Ryrie; for exceptions, see Harvey 1983, and White 1974]. But the recession of the 1980s has probably increased pressure on donor governments to tie aid, and to use it to help troubled domestic contractors. This inevitably reduces the efficiency of recipients' capital stock [Griffin] and therefore aid-effectiveness.

\section{IV}

The strongest message of these papers, however, is about donor-recipient interactions. The simpler form of that message is that, where aid is a large part of public expenditure, especially in Bangladesh and much of Africa [Van Arkadie, Chaudhuri, Duncan], recipients' errors and donors' errors reinforce one another, each rendering the other harder to correct. Thus donors' complex and distinct aid procedures and requirements, which 'often reflect inertia or convenience rather than economic interest or doctrine', divert the recipient's scarce administrative skills - and policy analyses - from development management to aid management [Van Arkadie]; the donors' 'disbursement imperative' pushes recipients towards over-rapid replication of pilot projects [Toye]; and both tendencies, plus project proliferation [Duncan, Ryrie, Van Arkadie], divert or reduce central policymaking capacity and thus help to cause the domestic policy omissions, so harmful to aid-effectiveness, of which donors later complain. Conversely, recipient ministries, by competing for tied aid projects with hidden costs [Van Arkadie], encourage donors to act in ways later judged aid-ineffective by recipient governments.

If that were all, then 'coordination' - of recipient ministries, of donor procedures, and of donors with the recipient Planning or Finance Ministry - would be an obvious solution. It is costly, and it provokes the question: who shall coordinate the coordinators? Yet it is a solution with which many of these papers concur, whilst cautioning (hopefully?) that donors should coordinate to avoid presenting Kenyans with 18 varieties of water pumps with non-interchangeable spares [Duncan, Mosley], or Bangladeshis with even more varieties of project procedure, but not to gang up on the recipient with agreed macroconditions for aid [Daniel, Van Arkadie] that may reflect no more than current dogma - Fabian yesterday, neo-classical today, tomorrow what: ecological, monetarist, feminist, moral-majoritarian?

Still, coordination is a Good Thing. Unfortunately it falls foul of a more complex, deeper reason why donor and receipt errors in aid management reinforce each other. That reason is as follows. Each donor wants to use aid, quite legitimately, to further self-interest commercial, political, even military - as well as development. Each donor knows that such attempts largely cancel each other out, leaving no donor better off, incompetent donor companies baled out, aid less effective, and recipients resentful. Yet each donor fears that, if it ceased to use 'training' to push its own doctrines or products, or allowed recipients to treat its aid projects normally rather than as privileged islands with rules of their own, or (in the case of bilateral donors) untied its aid, then it would lose out to less scrupulous donors. A coordinating agreement would be useless, since who would enforce it, or police the cheats? (Hence the sad death of moves towards multilateral untying.) Exactly similarly, each recipient ministry knows that its efforts to raise its share in foreign aid, and to evade the aid rules, are largely cancelled out by the efforts of other ministries, leaving aid less effective and wasting time; yet each ministry fears that abstention from lobbying will not be matched - nor agreements to abstain respected - by its 'colleagues'. So both donors and recipient ministries, each group imprisoned in its dilemma, put up with aid much less effective than it might be. If this analysis is right, it casts doubt on coordination, conditionality, and even policy dialogue as paths to greater aid-effectiveness - and underlines the need for donors to concentrate aid upon countries relatively immune from the perverse competition described above.

Consider aid tying. Each donor pushes its own technology, usually inappropriate - in Kenya, too capital-intensive for drinking-water supply [Duncan], too diverse and inconsistent for water pumps [Mosley]. Yet, if just one donor unties, it loses. Until donors come to believe in one another's virtue - or in a (hitherto unenforceable) agreement to untie - how is coordination feasible?

Or consider the drive to disburse - the sudden replication of success at Comilla, Bangladesh, into near disaster with IRDPs (Integrated Rural Development Programme) in 410 thanas (rural block; population typically about $0.2 \mathrm{mn}$ ); the rush to spread training-and-visit extension, or warabandi irrigation, in India [Toye]; the extreme, last-minute rush to get the money out at the end of each financial year [Ryrie]. Each donor, each ministry, fears to be upstaged by the others. Again, trust or enforcement - neither very likely - seems a necessary precondition for coordination.

Perhaps most seriously, take the propensity of each donor to seek special favours for its projects. Often, donors demand for their projects the status of areaspecific islands, free from normal ministerial pro- 
cedures, each with its donor-specific system, yet each stretching to rupture the recipient's limited capacities for cross-ministry coordination, and fragmenting and impoverishing the national administrative system [Van Arkadie; Toye, on community development; or 'rent-a-district' in Sri Lanka]. Sometimes such approaches succeed, as with Kenya's Semi-arid Lands Programmes [Duncan]; or with some Sri Lankan district IRDPs. And some countries, like Malawi, minimise the problems by concentrating on few donors and projects [Hewitt and Kydd]. Yet even the complex, distinctive procedures of planning the aid cycle created by each donor [Ryrie] - while legitimate, if not inevitable - create major problems for recipients, worsening the returns to all donors' aid. Yet which donor will disarm - will simplify, homogenise or coordinate its aid procedures, and align project requirements to normal recipient practices - unless it can trust other donors similarly to abandon a search for special project advantages, even if that search ultimately damages all projects?

Recipient ministries behave like donors, imprisoned in the same dilemma. Bangladesh has its "coordinating agency', yet major ministries continue to lobby for bigger shares of the (more or less fixed) aid total [Van Arkadie].

These problems, while not solved, would be less damaging to aid-effectiveness if each recipient had to deal with fewer competing donors. This is illustrated by the much greater success of Malawi than of Bangladesh in coordinating and concentrating aid and avoiding undue diversions of internal resources to its management [Hewitt and Kydd, Van Arkadie]. Rapid personnel turnover, interacting with a large number of donors, makes it even harder for recipient ministries to achieve coherence [Van Arkadie]. Each donor too, might better serve its interests by concentration [Ryrie] - but may fear that other donors would 'take advantage' to seize commercial and political gains in the territory from which rival donors had retreated. So even attempts to simplify the aid problems generated by 'prisoners' dilemma' fall victim to it. There may nevertheless be enough recognition of the costs of fragmented aid to create a 'head of steam' behind coordination. But the barriers to major advance are fundamental.

\section{V}

In 1978-84, several factors combined to bring about a shift from project aid to balance-of-payments support - to programme aid, structural adjustment loans, aid for maintenance and rehabilitation. First, drought, debt and slump - and even the past policies of donors, eg in Kenya [Duncan], expansionism after the 1976-77 coffee boom; and in Malawi [Hewitt and
Kydd], IRDPs with surprisingly costly recurrent import costs - meant that many recipients could not afford imports to run and maintain existing roads, dams and factories; it made little sense for donors to help build more, and much sense to increase current import levels. Second, some recipients' policies were increasingly felt by donors to reduce the effectiveness of project aid (Section III). Third, donors' competing projects and 'disbursement imperatives' were felt by recipients to bring increasing costs, relative to programme aid.

Donors owe their taxpayers some evidence of aideffectiveness. At project level, such evidence is available, and donors think they know what conditions to seek for projects they back; recipients accept that. But aid to a programme of investment is tested by the success of that programme. Hence, partly to convince taxpayers that programme aid is effective (and also partly to make projects work better), donors increasingly try to impose or negotiate programme conditions.

The Indian aid experience of the 1960s [Daniel, referring to Lipton, Toye and Cassen, 1984] provides clear warnings of what fails, and guidelines to what might work, in respect of programme conditions. Attempts to impose grand macroeconomic strategies, unbacked by deep analysis or mutual learning, and followed by failure to deliver the aid even when the (ill-timed) conditions were met, are well known in India, but were discredited by the 1965-67 devaluation saga. The aid relationship took several years to recover, but since the mid-1970s genuine policy dialogue - mutual learning - has brought major policy changes (albeit controversial, and probably spread too fast beyond the pilot stage) in agricultural extension, irrigation design, and other areas [Toye, Daniel]. Before this experience, a long process of institutional learning in the largest economic sector, agriculture, had taken place; the 'lessons' of extension (community development), price policy, and technical but field-tested biological research and diffusion were learned sequentially, each partial success revealing the inadequacies in other policy regions [Toye].

Yet macro-conditionality in Africa largely ignores the Indian lessons. The tone has been set, not by donors such as the World Bank with its steady learning and rejection of uniform prescriptions, but by the Fund, compelled by its Articles [Daniel] - and by the lack of an alternative theory of adjustment? - to impose the 'three Ds' of deficit management: deflation, decontrol, devaluation. Reforms, often badly needed, are insisted upon in abrasive ways that, as in Tanzania, actually delay reform [Daniel, Van Arkadie]; with little information about timing, or about how supply 
will respond to the incentive; and, as the World Bank increasingly notes, with distressingly little power to persuade donors to expand aid if recipients do meet macro-conditions. Even aid coordination, desirable to harmonise donor procedures and equipment and to save recipient time, can dangerously shade into agreement to impose a macro-condition reflecting current dogma or fashion [Van Arkadie]. Moreover, macro-conditions tend to work only when they 'push at an open door' - when as in Malawi [Hewitt and Kydd] they can help, encourage and accelerate actions the government wished to take anyway. 'Macroconditions are fungible, as well as project aid' [Mosley]. Where a government "complies against [its] will, 'tis of the same opinion still' [Butler 1694]; external conditions imposed on Kenya were similar to the internal advice of the Ndegwa Committee, but the government, unwilling to reform grain marketing, found ways to get round that condition [Duncan]. The World Bank's Operations Evaluation Division, reporting on the fate of macro-conditions upon its Structural Adjustment Loan to Turkey, stressed the key role of (a) prior political accord, and (b) a realistic, not-too-rapid schedule for implementing the conditions.

The Indian precedent strongly suggests that successful policy dialogue in Africa, too, must shift, from instant macro-conditions based on textbook blueprints, towards low-pressure and sector-specific measures agreed after a longish process of mutual learning, and based on the development of appropriate technical packages and institutions, as well as price incentives [Daniel]. Institutional transfer does best to start from local social realities, not from false analogies to the universalism of natural science [Toye]; direct institutional copying by donors, eg from West German border-town development to growth poles in Malawi [Hewitt and Kydd] or from US count ry agents to Indian extension workers [Toye], is seldom, though not never, cost-effective.

Useful sector dialogue in Africa will require major expansion of manpower aid [Ryrie], not least to increase recipient capacity for policy analysis [Daniel]. Currently, it is often a dialogue of the dumb, especially on agriculture, where very few donor or recipient officials - at least in difficult cases like Zaire - have enough prolonged experience of local farming systems and responses. Manpower aid has a good record in Asia, from the very same donor agencies that so seldom perform well in Africa [Muscat]. Part of the reason for this is the complete absence of any good, tested, or conceptually rich theory of the optimal rate at which various parts of a very underdeveloped manpower system should become self-reliant [Muscat]; certainly most donors, and recipients, have assumed wildly unrealistic rates of feasible 'Africanisation' in many sectors [Ryrie], while proliferating complex and capital-intensive projects - and policies - that needed yet more experts.

\section{VI}

While all this will help, there is a limit to which manpower aid, institution-building, or consequent mutual sector-specific learning - any more than the dubious paths of macro-conditionality - can 'persuade a leopard to change its spots' [Mosley]. As with aid for poverty alleviation [Chaudhuri] and for primary health care [White, de Kadt and Andersson 1979], so with aid-effectiveness overall: perhaps each donor should, rather, concentrate funds on fewer than (say) the UK's 125 recipients [Ryrie] - and on recipients which, subject to donor national interests, meet its own standards of aid-effectiveness. If that led each recipient to an aid pattern concentrated on fewer donors, that would, as in Malawi, ease the problems of project proliferation and aid management [Hewitt and Kydd], thereby raising aid-effectiveness further.

Whether on project performance [World Bank 1985] or on cross-section indicators [Mosley 1986], aid to Asia is much more effective than aid to Africa. Yet poor African countries get much more aid-per-person than poor Asian countries, and the disparity is widening [OECD 1984]. This is bound to damage aid-effectiveness, though the continental division is much too crude - there are some Asian failures, and several African successes eg Malawi, Cameroons, Rwanda, Botswana, and until recently Kenya and the Ivory Coast.

There are some respects in which aid allocation among countries is little short of a scandal. Miniscule and wealthy French islands electing députés to the French Parliament, Soviet puppet states and janissary states, US military client states in West Asia and Latin America - these absorb very large proportions of scarce aid, which is thus denied to the efficient poor. In $1982,34.1$ per cent of allocable aid went to countries containing 2.7 per cent of the population of the developing world - mostly in middle-income countries; they enjoyed $\$ 102$ of net aid disbursements per person in that year. The remaining $3.3 \mathrm{bn}$ people of the Third World each received $\$ 5.60 .^{3}$ In the circumstances it is astonishing that the 'aid community', donor and recipient, attains the modest but - until recently, and outside Africa still satisfactory level of aid-effectiveness revealed in these papers.

\footnotetext{
3 See OECD [1984]. This refers to total net aid disbursements, from multilateral agencies and bilaterally from OECD, OPEC, and CMEA countries. Each of the three groups makes a major contribution to the concentration of aid on a few, mostly small, countries. If China is excluded - but why? - the above disparity becomes only slightly less outrageous.
} 


\section{References}

Burki, S. J. and R. Ayres, 1986, 'A fresh look at development aid', Finance and Development, Vol 23 no 1, pp6-10

Butler, S., 1694, Hudibras, London

Cassen, R., 1986, 'Summary and Conclusions' in his Does Aid Work?, Oxford University Press

-1986a, 'The effectiveness of aid', Finance and Development vol 23 no 1 , ppl1-14

Harvey, C., 1983, Analysis of Project Finance in Developing Countries, Heinemann, London

Krueger, Anne O., 1986, 'Aid in the development process', World Bank Research Observer, vol 1, no 1, January

Lavy, V., 1985, 'Anticipated development assistance, temporary relief aid and consumption behaviour of lowincome countries', Discussion Paper, World Bank, Washington DC

Lipton, M., J. Toye and R. Cassen, 1986, in R. Cassen (ed.), Does Aid Work?, Oxford University Press
Mosley, P., 1980, 'Aid, savings and growth revisited', Oxford Bulletin of Economics and Statistics, vol 42, no 2

- 1986, J. Hudson and S. Horrell, 'Aid, the public sector and the market in less developed countries', Economic Journal

Papanek, G., 1972, 'The effect of aid and other resource transfers on savings and growth in less developed countries', Economic Journal, vol 82, September

OECD (DAC), 1984, Development Co-operation, Paris

Weisskopf, T., 1972, 'The impact of foreign capital inflow on domestic savings in underdeveloped countries', Journal of International Economics, vol 2, no 1, February

White, A., E. de Kadt, and N. Andersson, 1979, 'Health Aid: A Comparative Study of Three Donor Countries', in Two Papers on Health Aid, Communication 123, IDS, Sussex

White, J., 1974, The Politics of Foreign Aid, St. Martins, London

World Bank (Operations Evaluation Division), 1985, Annual Review of Project Performance Results, Report No. 5859 Washington DC 